Article

\title{
Effect of a Diet Supplemented with the Moringa oleifera Seed Powder on the Performance, Egg Quality, and Gene Expression in Japanese Laying Quail under Heat-Stress
}

\author{
Reham Abou-Elkhair ${ }^{1, *}$, Heba Abdo Basha ${ }^{2}$, Walaa Slouma Hamouda Abd El Naby ${ }^{3}$, \\ Jamaan S. Ajarem ${ }^{4}$, Saleh N. Maodaa ${ }^{4}$, Ahmed A. Allam ${ }^{5}$ and Mohammed A. E. Naiel ${ }^{6,}$ \\ 1 Nutrition and Clinical Nutrition Department, Faculty of Veterinary Medicine, University of Sadat City, \\ Al Buhayrah, Menofia 32958, Egypt \\ 2 Poultry Breeding and Production in Department of Animal Husbandry and Animal Wealth Development, \\ Faculty of Veterinary Medicine, Alexandria University, Alexandria 21500, Egypt; heba.basha@alexu.edu.eg \\ 3 Genetics and Genetic Engineering in Department of Animal Husbandry and Animal Wealth Development, \\ Faculty of Veterinary Medicine, Alexandria University, Alexandria 21500, Egypt; \\ walaa.hamouda@alexu.edu.eg \\ 4 Department of Zoology, College of Science, King Saud University, P.O. Box 2455, Riyadh 11451, Saudi Arabia; \\ jajarem@ksu.edu.sa (J.S.A.); maodaa_28@yahoo.com (S.N.M.) \\ 5 Department of Zoology, Faculty of Science, Beni-suef University, Beni-suef 65211, Egypt; \\ allam1081981@yahoo.com \\ 6 Department of Animal Production, Faculty of Agriculture, Zagazig University, Zagazig 44511, Egypt \\ * Correspondence: reham.abouelkhair@vet.usc.edu.eg (R.A.-E.); \\ mohammednaiel.1984@gmail.com (M.A.E.N.)
}

Received: 7 March 2020; Accepted: 4 April 2020; Published: 7 May 2020

Simple Summary: The debilitating effect of heat stress on egg production is well known, but its mechanism is not understood. Some studies attribute for this bad effect on the reduction in feed intake to high temperature or the relation between heat stress and reproductive and ovarian dysfunction, which cause a lowering in egg production. Heat stress directly affects ovarian function by altering the secretion of ovarian hormones such as prolactin. Moringa seed powder plays an effective role in overcoming the effect of heat stress, through the flavonoids and other phenolic compounds present in it. Hence, we investigated the effect of feeding Moringa oleifera seed powder with different concentrations, on egg production, egg quality trait, and the expression levels of selected ovarian genes in quail layers subject to heat stress. We found that supplementing laying Japanese quail feed with the Moringa oleifera seed powder at level $0.3 \%$ enhanced resistance to heat stress condition and consequently improved egg productivity.

Abstract: This study was conducted to evaluate the effect of three concentrations of the Moringa oleifera seed powder as a feed supplement on the productive performance and egg quality traits of laying Japanese quail (Coturnix japonica) exposed to heat stress. The expression patterns of the genes estrogen receptors (ESR2), follicle-stimulating hormone receptor (FSHR), prolactin receptor (PRLR), and steroidogenic acute regulatory protein (STAR) were estimated in ovaries, using a quantitative real-time polymerase chain reaction. A total of 200 laying quail aged seven weeks were randomly allocated to the following four experimental groups - the control (CNT), T1, T2, and T3 groups; each group comprised 50 quail females with 5 replicates (10 per group). The CNT group was fed a basal diet, whereas the T1, T2, and T3 groups were fed the basal diet supplemented with $0.1 \%$, $0.2 \%$, and $0.3 \%$ M. oleifera seed powder, respectively. The results revealed that the T3 group showed the highest hen-day egg production (\%) as well as the highest egg yolk index. Feed intake and feed conversion ratio improved significantly $(p<0.05)$ with increased concentrations of the M. oleifera 
seed powder supplementation. Furthermore, the mRNA expressions of ESR2, FSHR, and STAR increased significantly in the T3 group, compared to those in the CNT group. Alterations in ovarian gene expressions corresponded to the reproductive patterns of the treated Japanese quail. Thus, it was concluded that the supplementation of the Japanese quail feed with $0.3 \% \mathrm{M}$. oleifera seed powder during the laying period might enhance resistance to heat stress and consequently improve egg productivity.

Keywords: Moringa oleifera; gene expression; reproductive; heat stress; quail

\section{Introduction}

Eggs are considered to be one of the most valuable daily foods, such that the poultry egg industry has been intensively growing to meet the increased demand for eggs. Quail eggs can be used besides chicken eggs to meet this demand, and despite their small size, they exhibit several nutritional benefits because they are richer in protein, fat, vitamins, and minerals (iron, potassium, and zinc) than chicken eggs [1,2]. In addition, it has been claimed that the eggs from Japanese quail are rich sources of protein with low fat and cholesterol [3]. Thus, many people, especially in Asian countries, consume quail eggs because they are a good source of nutrients for human health and help in the treatment of tuberculosis, bronchial asthma, and diabetes diseases [4].

Even at present, global warming has been affecting the poultry industry, in that high environmental temperatures impose severe stress on laying birds, thus, resulting in reduced egg production and increased economic loss [5]. The adverse effect of heat stress results in a reduced feed intake [6,7] as well as a reduced egg production [8], by modifying neuroendocrine activity by stimulating the hypothalamic-pituitary axis. Furthermore, heat stress negatively affects reproductive activity and ovarian function, eventually reducing egg production [8]. Heat stress directly affects ovarian function by altering folliculogenesis and the secretion of ovarian hormones, such as prolactin, luteinizing hormone (LH), and follicle-stimulating hormone (FSH) [9]. Ovarian functions and folliculogenesis are mainly controlled by various genes, such as steroidogenic acute regulatory protein (STAR), inhibin subunit alpha (INHA), bone morphogenetic protein 15 (BMP-15), follicle-stimulating hormone receptor (FSHR), and estrogen receptors 1 and 2 (ESR1 and ESR2) [10-14].

Several studies have examined technical options such as nutritional manipulation and feed additives to alleviate the harmful effect of heat stress on laying birds [7,15-17]. Natural herbal plants, such as black seed, coriander seeds, and Moringa oleifera exhibit effective roles in overcoming the effect of heat stress through flavonoids and other phenolic compounds $[18,19]$. M. oleifera has a high nutritional value as it comprises significant concentrations of vitamins $\mathrm{A}, \mathrm{B}$, and C, proteins, phosphorus, and calcium [20,21]. Moreover, it is rich in flavonoids, carotenoids, tocopherols, selenium, and vitamin E [22,23] and has a potent antioxidant activity [24,25]. In addition, Ashour et al. [26] reported significantly increased egg production and improved hatchability, along with some egg quality parameters, and also lowered some blood biochemical components in Japanese quail that were fed an M. oleifera seeds-supplemented diet. Additionally, Lan et al. [27] revealed that supplementation of Moringa leaf powder at $5 \%$ had no effect on the performance of laying quail but remarkably enhanced yolk color. It is well-known that heat stress promotes oxidative stress in body cells, thereby, interrupting ovarian functions. In this context, the present study aimed to investigate the effects of feeding different concentrations of the $M$. oleifera seed powder on egg production, egg quality traits, and selected ovarian gene expressions in laying quail that were subject to heat stress. 


\section{Materials and Methods}

All procedures by this study were in accordance with international ethical standards. The research involved no human participants. All animal procedure was performed following the guidelines for care and use of laboratory animals of the International Council for Laboratory Animals (ICLAS-2015). All procedures and experiments were accepted and approved by the local ethics committee of animal use, the Institutional Animal Care and Use Committee (AU-IACUC), Faculty of Veterinary Medicine, Alexandria University.

\subsection{Animals, Housing, and Experimental Design}

A total of 200 seven-week-old laying quail (Coturnix japonica) with an initial live weight of $140 \pm 5 \mathrm{~g}$ was allocated to four groups-the CNT, T1, T2, and T3 groups; each group comprised 50 quail with 5 replicates (10 per group). The CNT group was administered a corn-soybean basal diet in a mash form without any additives. The basal diet was formulated to meet the nutritional requirements, according to the recommendation of the National Research Council (NRC) [24]. M. oleifera seed powder was obtained from the Agricultural Research Centre, Giza, Egypt (see Table 1). The ingredients, nutrient concentration, and chemical composition [28] of the basal diet are shown in Table 2. The T1, T2, and T3 groups were administered the same basal diet supplemented with $0.1 \%, 0.2 \%$ and $0.3 \%$. M. oleifera seed powder, respectively. Approximately $30 \pm 5 \mathrm{~g}$ per bird of food and water were available at all times during the experiment. During the pre-laying period, the quail were fed a commercial grower diet. The experiment was initiated at 7 weeks of age and completed at 15 weeks of age. The lighting regimen was $16 \mathrm{~h}$ of continuous light per day. All groups were exposed to heat stress $\left(35 \pm 1^{\circ} \mathrm{C}\right)$ throughout the experimental period, using an electrical heater.

Table 1. Composition and nutrient content (per $100 \mathrm{~g}$ plant) of the Moringa oleifera seeds powder.

\begin{tabular}{lc}
\hline \multicolumn{1}{c}{ Parameter } & Amount \\
\hline Moisture (g) & 8 \\
Crude protein (g) & 36 \\
Crude fat(g) & 37.2 \\
Carbohydrate (g) & 7.9 \\
Fiber (g) & 3.1 \\
Ash (g) & 14.2 \\
Calcium (mg) & 45 \\
Magnesium (mg) & 598 \\
Phosphorus (mg) & 73 \\
Potassium (mg) & 7 \\
Copper (mg) & 4.2 \\
Iron (mg) & 2 \\
Sulfur (mg) & 0.05 \\
Vitamin E (mg) & 766 \\
Vitamin C (mg) & 6.5 \\
Total amino acids(g) & 20.2 \\
PUFA (mg) & 73 \\
\hline
\end{tabular}

Values in the table are those provided by the manufacturer (Agricultural Research Center, Giza, Egypt). PUFA - polyunsaturated fatty acids (linoleic, linolenic, and oleic acid). 
Table 2. Composition and nutrient level of the basal diet on a dry matter basis.

\begin{tabular}{lc}
\hline \multicolumn{1}{c}{ Items } & Amount \\
\hline Ingredients, \% & \\
Yellow corn & 56 \\
Soybean meal (44\%) & 29.29 \\
Corn gluten meal & 3.8 \\
Vegetable oil & 3.5 \\
Salt & 0.31 \\
Dicalcium phosphate 1 & 1.1 \\
Premix ${ }^{2}$ & 0.25 \\
Limestone & 5.6 \\
DL-Methionine ${ }^{3}$ & 0.11 \\
L-lysine & 0.04 \\
Total & 100.00 \\
Energy and Nutrient level & \\
ME (Kcal /kg) & 2979 \\
Crude protein \% & 19.9 \\
Ether extract \% & 5.9 \\
Crude fiber \% & 3.3 \\
Calcium \% & 2.461 \\
Available phosphorus\% & 0.33 \\
Methionine \% & 0.454 \\
Lysine & 1.002 \\
Methionine + cysteine & 0.788 \\
\hline
\end{tabular}

\footnotetext{
${ }^{1}$ Dicalcium phosphate, $18 \%$ granular phosphate, and $23 \%$ calcium. ${ }^{2}$ Supplied per kilogram of diet: Vitamin A 12,000 IU, vitamin D3 3000 IU, vitamin E 40 mg, vitamin K3 3 mg, vitamin B1 2 mg, vitamin B2 6 mg, vitamin B6 $5 \mathrm{mg}$, vitamin B12 $0.02 \mathrm{mg}$, niacin $45 \mathrm{mg}$, biotin $0.075 \mathrm{mg}$, folic acid $2 \mathrm{mg}$, pantothenic acid $12 \mathrm{mg}$, manganese 100 $\mathrm{mg}$, zinc $600 \mathrm{mg}$, iron $30 \mathrm{mg}$, copper $10 \mathrm{mg}$, iodine $1 \mathrm{mg}$, selenium $0.2 \mathrm{mg}$, and cobalt $0.1 \mathrm{mg}$. ${ }^{3}$ DL-Methionine, Met $\mathrm{AMINO}^{\circledR}$ (DL-2-amino-4-(methyl-thio)-butane acid, DL-methionine, $\alpha$-amino-Y-methyl-oily acid) by Feed Grade 99\% (EU).
}

\subsection{Productive and Reproductive Measurements}

Eggs were collected daily, and hen-day egg production (\%) was calculated. Egg weight and feed consumption were recorded on five replicates, at weekly intervals. Feed conversion ratio (FCR) was estimated as the ratio of feed consumed (g)/egg weight (g).

\subsection{Sample Collection and Egg Quality Measurements}

Twenty-five eggs were randomly collected from quail in each treatment group ( 5 eggs/replicate), at 11 and 15 weeks of age, to evaluate the egg quality parameters. Shell thickness (without the inner and outer shell membranes) was measured at the blunt, equatorial, and sharp regions to obtain an average value [29].

Egg components, including the shell, albumen, and yolk, were weighed separately and expressed as percentages. The egg shape index was calculated according to the method described in [27]. Egg yolk index was calculated according to the method described by Romanoff and Romanoff [30]. The Haugh unit was estimated according to the method reported by Cotta [31].

At the end of the experiment when the quail were 15 weeks of age, 25 quail from each treatment group ( 5 birds/replicate) were randomly selected and slaughtered, and the whole ovaries were quickly removed and weighed. The tissue samples were homogenized, immediately snap-frozen in liquid nitrogen, and stored at $-80{ }^{\circ} \mathrm{C}$, until further use.

\subsection{Total RNA Isolation and cDNA Synthesis}

Total RNA was isolated from the ovaries using the Biozol reagent (Bioflux, Japan), according to the manufacturer's instructions. cDNA was synthesized using the Sensi FAST ${ }^{\mathrm{TM}} \mathrm{CDNA}$ Synthesis Kit (Bioline, United Kingdom), according to the manufacturer's instructions. In brief, $4 \mu \mathrm{L}$ total RNA was 
mixed with $4 \mu \mathrm{L} 5 \times$ Trans Amp buffer, $1 \mu \mathrm{L}$ reverse transcriptase, and $11 \mu \mathrm{L}$ RNase/DNase-free $\mathrm{H}_{2} \mathrm{O}$. The thermal cycler program was conducted as follows $-25^{\circ} \mathrm{C}$ for $10 \mathrm{~min}, 42{ }^{\circ} \mathrm{C}$ for 15 min (reverse transcription), and $4^{\circ} \mathrm{C}$ hold. The integrity of the cDNA was determined by amplification of $\beta$-actin, and the sample was then stored at $-20^{\circ} \mathrm{C}$ until further use.

\subsection{Quantitative Real-Time Polymerase Chain Reaction (PCR)}

Quantitative real-time PCR was conducted to reveal the expression profiles of ESR2, FSHR, STAR, and PRLR, as described previously by Abd El Naby and Basha [32]. Primer sequences and annealing temperatures for the real-time PCR are listed in Table 3. The housekeeping gene $\beta$-actin was used as the normalization control. Relative mRNA expression was calculated using the $2^{(-\Delta \Delta \mathrm{ct})}$ method, and the results were reported as a fold change [33].

Table 3. Used primers for the quantitative real-time PCR.

\begin{tabular}{|c|c|c|}
\hline Product Length (bp) & Primer Sequence $\left(5^{\prime}-3^{\prime}\right)$ & Gene and ID \\
\hline ESR2 & F: TCACCTGCTGGTATTGGCTC & \multirow{2}{*}{83} \\
\hline (XM_015865466.1) & R: GGGATGTAGACTGGACTGTGT & \\
\hline FSHR & F: CTCTCGGTCTACACGCTGAC & \multirow{2}{*}{77} \\
\hline (XM_015856889.1) & R: TTGCGGTTAAGTTGCATGGC & \\
\hline STAR & F: ATCCCAGCGTCAAAGAGGTG & \multirow{2}{*}{98} \\
\hline (XM_015883089.1) & R: CCCAATGATGTTCCCAGGCA & \\
\hline PRLR & F: AAATGCTGGCGTGAGGTACA & \multirow{2}{*}{99} \\
\hline (NM_001323231.1) & R: CCACTGGGGATCAGAATCCG & \\
\hline$\beta$-actin & F: ATGGCTCCGGTATGTGCAA & \multirow{2}{*}{120} \\
\hline (NM-205518.1) & R: TGTCTTTCTGGCCCATACCAA & \\
\hline
\end{tabular}

$E S R 2$ = Estrogen receptor 2 (ER beta), FSHR = Follicle stimulating hormone receptor, STAR = Steroidogenic acute regulatory protein, $P R L R=$ Prolactin receptor, and $B$-actin $=$ Beta actin.

\subsection{Statistical Analysis}

Experimental data were analyzed through one-way ANOVA, using the SAS (Statistical Analysis System, version $6,4^{\text {th }}$ Edition, SAS Institute, Cary, NC, USA). Prior to ANOVA analysis, all data were tested for normality using the Shapiro-Wilk test [34]. Data are expressed as mean \pm standard error of the mean, and significance was considered at $p<0.05$. Analyses of significant treatment and replicate effects were performed using multiple range comparisons with Duncan's multiple range test [35]. The quantitative real-time PCR data obtained were analyzed using the GraphPad Prism software version 6 (GraphPad Prism Software, La Jolla, CA, USA), through statistical analysis of one-way analysis of variance (ANOVA).

\section{Results}

\subsection{Productive and Laying Performance}

The effects of different concentrations of the Moringa oleifera seed powder as a feed additive on the productive and laying performance of quail are summarized in Table 4 . In the first 4 weeks of the experiment, no significant differences were observed in egg weight and feed intake among the treatment groups. In the next 4 weeks of the experiment, the administration of the Moringa oleifera seed powder increased the egg weight in descending order; T2, T3, and T1 groups, but decreased feed intake. The T2 and T3 groups showed the highest egg weight and the lowest feed intake during 11-15 weeks of age. Generally, laying quail fed a diet supplemented with Moringa oleifera seed powder had better feed conversion ratio and egg production $\%(p<0.01)$ during the period $7-15^{\text {th }}$ weeks of age than the control birds. The T3 group, which received the highest concentration ( $0.3 \%)$ of the Moringa 
oleifera seed powder, had the lowest FCR and the highest egg production (\%), as compared to the other treated groups.

Table 4. Effect of the Moringa oleifera supplementation on the laying performance of Japanese quail, during the experimental period.

\begin{tabular}{|c|c|c|c|c|c|c|}
\hline \multirow{2}{*}{ Item $^{1}$} & \multicolumn{5}{|c|}{ Dietary Treatments ${ }^{2}$} & \multirow{2}{*}{ Sig. } \\
\hline & Weeks & CNT & T1 & T2 & T3 & \\
\hline \multirow{2}{*}{ Egg weight (g/egg) } & $7^{\text {th }}-11^{\text {th }}$ & $11.41 \pm 0.25$ & $11.66 \pm 0.25$ & $11.73 \pm 0.26$ & $11.55 \pm 0.25$ & N.S. \\
\hline & $11^{\text {th }}-15^{\text {th }}$ & $11.27 \pm 0.27^{c}$ & $12.07 \pm 0.27^{b}$ & $12.91 \pm 0.27^{a}$ & $12.29 \pm 0.28^{a b}$ & $* *$ \\
\hline \multirow{2}{*}{ Egg production (\%) } & $7^{\text {th }}-11^{\text {th }}$ & $50.51 \pm 1.81^{\mathrm{c}}$ & $52.08 \pm 1.76^{c}$ & $59.37 \pm 0.76^{b}$ & $62.20 \pm 1.44^{\mathrm{a}}$ & $* *$ \\
\hline & $11^{\text {th }}-15^{\text {th }}$ & $48.38 \pm 1.95^{c}$ & $58.97 \pm 1.87^{b}$ & $57.52 \pm 1.11^{b}$ & $65.06 \pm 1.91^{\mathrm{a}}$ & $* * *$ \\
\hline \multirow{2}{*}{ Feed intake (g/bird) } & $7^{\text {th }}-11^{\text {th }}$ & $34.75 \pm 0.85$ & $33.75 \pm 0.63$ & $34.50 \pm 1.71$ & $32.00 \pm 1.63$ & N.S. \\
\hline & $11^{\text {th }}-15^{\text {th }}$ & $33.75 \pm 0.25^{b}$ & $38.50 \pm 1.19^{a}$ & $29.75 \pm 1.25^{c}$ & $30.75 \pm 0.63^{c}$ & $*$ \\
\hline \multirow{2}{*}{ Feed conversion ratio } & $7^{\text {th }}-11^{\text {th }}$ & $3.08 \pm 0.10^{\mathrm{a}}$ & $2.65 \pm 0.18^{b}$ & $2.80 \pm 0.20^{b}$ & $2.70 \pm 0.17^{b}$ & * \\
\hline & $11^{\text {th }}-15^{\text {th }}$ & $3.11 \pm 0.09^{a}$ & $2.81 \pm 0.10^{b}$ & $2.49 \pm 0.09^{c}$ & $2.47 \pm 0.99^{c}$ & $* *$ \\
\hline
\end{tabular}

${ }^{1}$ Feed conversion ratio $=$ feed intake $(\mathrm{g}) / \mathrm{egg}$ mass $(\mathrm{g})$; Egg production $=100$ [number of eggs laid $\div$ (number of hens $x$ number of days)]. ${ }^{2}$ CNT, Control group; T1, $0.1 \%$ Moringa oleifera seed powder; T2, $0.2 \%$ Moringa oleifera seed powder; T3, $0.3 \%$ Moringa oleifera seed powder. ${ }^{a, b, c}$ values in the same row with a different superscript differ significantly at $p<0.05$. Sig.- significance; N.S.-non-significance; ${ }^{*} p<0.05,{ }^{* *} p<0.01,{ }^{* * *} p<0.001$.

\subsection{Egg Quality Measurements}

Data regarding egg quality parameters at the end of the 4th and 8th weeks of the experiment are presented in Table 5. No significant differences were observed in egg quality traits—shell thickness, albumen (\%), yolk (\%), egg yolk index, egg shape index, and the Haugh unit between the CNT and the TI, T2, and T3 groups at the end of 4th week of the experiment. Furthermore, the supplementation of M. oleifera seed powder in the diet did not affect the egg shape index and the Haugh unit at the end of the 8th week of the experiment. However, at the same age, the laying quail which received M. oleifera seed powder as a supplement had a higher shell thickness, albumen $(\%)$, and yolk $(\%)(p<0.01)$ than those who received the basal diet alone. The eggs of the quail in the T3 group recorded the highest significant egg yolk index.

Table 5. Effect of the Moringa oleifera supplementation on egg quality traits, in the 4th and 8th week of the experimental period.

\begin{tabular}{|c|c|c|c|c|c|c|}
\hline \multirow{2}{*}{ Item } & \multicolumn{5}{|c|}{ Dietary Treatments 1} & \multirow{2}{*}{ Sig. } \\
\hline & Week & CNT & $\mathrm{T} 1$ & T2 & T3 & \\
\hline \multirow{2}{*}{ Shell Thickness (mm) } & $4^{\text {th }}$ & $0.36 \pm 0.22$ & $0.38 \pm 0.15$ & $0.42 \pm 0.20$ & $0.33 \pm 0.23$ & N.S. \\
\hline & $8^{\text {th }}$ & $0.30 \pm 0.2^{b}$ & $0.39 \pm 0.1^{\mathrm{a}}$ & $0.42 \pm 0.25^{\mathrm{a}}$ & $0.39 \pm 0.17^{\mathrm{a}}$ & $* *$ \\
\hline \multirow{2}{*}{ Shell\% } & $4^{\text {th }}$ & $15.27 \pm 0.40$ & $14.26 \pm 0.50$ & $15.34 \pm 0.5$ & $14.08 \pm 0.46$ & N.S. \\
\hline & $8^{\text {th }}$ & $14.63 \pm 0.55^{b}$ & $14.27 \pm 0.45^{b}$ & $16.91 \pm 0.35^{\mathrm{a}}$ & $14.25 \pm 0.55^{b}$ & $* * *$ \\
\hline \multirow{2}{*}{ Albumin $\%$} & $4^{\text {th }}$ & $46.49 \pm 2.02$ & $47.91 \pm 2.27$ & $50.77 \pm 1.75$ & $49.84 \pm 2.02$ & N.S. \\
\hline & $8^{\text {th }}$ & $54.88 \pm 2.50^{b}$ & $54.17 \pm 2.48^{b}$ & $55.05 \pm 2.05^{b}$ & $57.46 \pm 1.99^{a}$ & $* *$ \\
\hline \multirow{2}{*}{ Yolk \% } & $4^{\text {th }}$ & $30.38 \pm 0.91^{b}$ & $32.06 \pm 0.97^{\mathrm{a}}$ & $33.30 \pm 0.74^{\mathrm{a}}$ & $32.88 \pm 0.85^{\mathrm{a}}$ & $*$ \\
\hline & $8^{\text {th }}$ & $29.30 \pm 1.40^{b}$ & $30.31 \pm 1.61^{\mathrm{ab}}$ & $31.97 \pm 1.40^{\mathrm{a}}$ & $30.11 \pm 0.99^{a b}$ & $* *$ \\
\hline \multirow{2}{*}{ Yolk Index } & $4^{\text {th }}$ & $0.32 \pm 0.012$ & $0.32 \pm 0.014$ & $0.32 \pm 0.015$ & $0.32 \pm 0.010$ & N.S. \\
\hline & $8^{\text {th }}$ & $0.38 \pm 0.012^{b}$ & $0.39 \pm 0.009^{b}$ & $0.38 \pm 0.013^{b}$ & $0.45 \pm 0.015^{\mathrm{a}}$ & $* *$ \\
\hline \multirow{2}{*}{ Egg Shape Index } & $4^{\text {th }}$ & $77.20 \pm 0.81$ & $77.75 \pm 0.82$ & $77.50 \pm 0.78$ & $78.52 \pm 0.80$ & N.S. \\
\hline & $8^{\text {th }}$ & $77.40 \pm 0.77$ & $76.75 \pm 0.92$ & $78.45 \pm 0.90$ & $79.05 \pm 0.80$ & N.S. \\
\hline \multirow{2}{*}{ Haugh Unit } & $4^{\text {th }}$ & $83.08 \pm 1.18$ & $84.61 \pm 1.16$ & $83.45 \pm 1.07$ & $82.50 \pm 0.98$ & N.S. \\
\hline & $8^{\text {th }}$ & $81.18 \pm 1.32$ & $81.14 \pm 1.27$ & $81.54 \pm 1.19$ & $82.31 \pm 1.22$ & N.S. \\
\hline
\end{tabular}

${ }^{1}$ CNT, Control group; T1, 0.1\% Moringa oleifera seed powder; T2, $0.2 \%$ Moringa oleifera seed powder; T3, $0.3 \%$ Moringa oleifera seed powder. ${ }^{a}, \mathrm{~b}$ values in the same row with a different superscript differ significantly at $p<0.05$. Sig.- significance; N.S. - non-significance; ${ }^{*} p<0.05,{ }^{* *} p<0.01,{ }^{* * *} p<0.001$.

\subsection{Expression Profiles of ESR2, FSHR, STAR, and PRLR}

The results of the expressions of the selected ovarian genes ESR2, FSHR, STAR, and PRLR are illustrated in Figure 1. The mRNA expressions of ESR2, FSHR, and STAR in the ovaries, increased significantly $(p<0.05)$ with increasing Moringa oleifera seed powder concentrations in the feed rations (T3 group), compared to the CNT group. However, the FSHR and STAR mRNA expressions showed 
significant decrease in T1 $(p<0.05)$ group compared to CNT group. The mRNA expressions of FSHR and ESR2 were significantly decreased in T2 $(p<0.05)$ group compared to the CNT. Finally, the mRNA expression of PRLR was increased in the T3, T2, and T1 groups compared to the CNT group, with the $\mathrm{T} 3$ group showing the highest expression.

ESR2

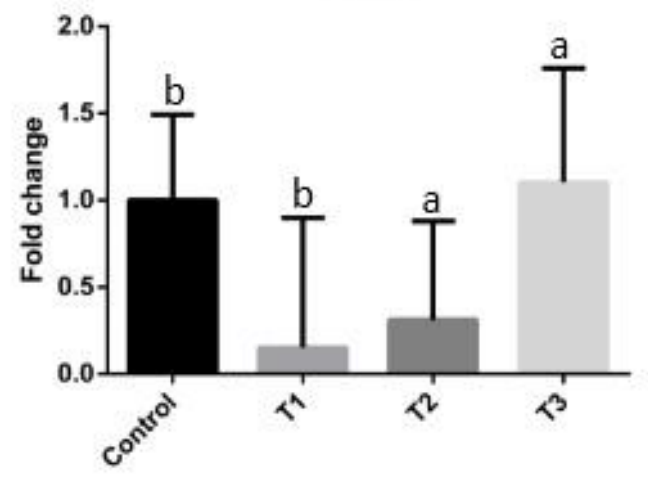

PRLR

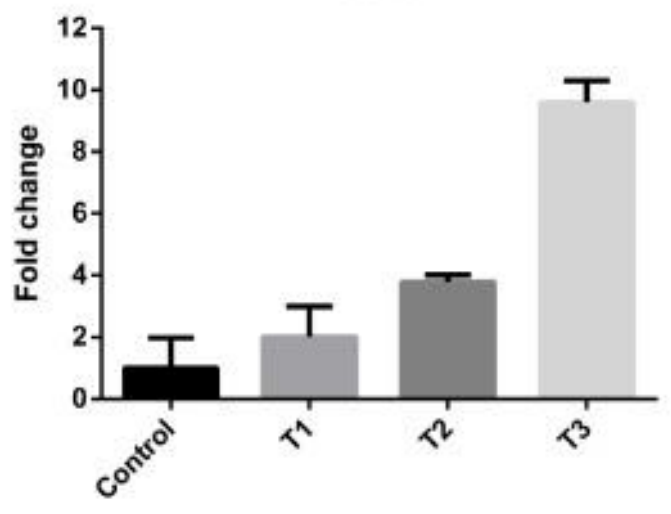

FSHR

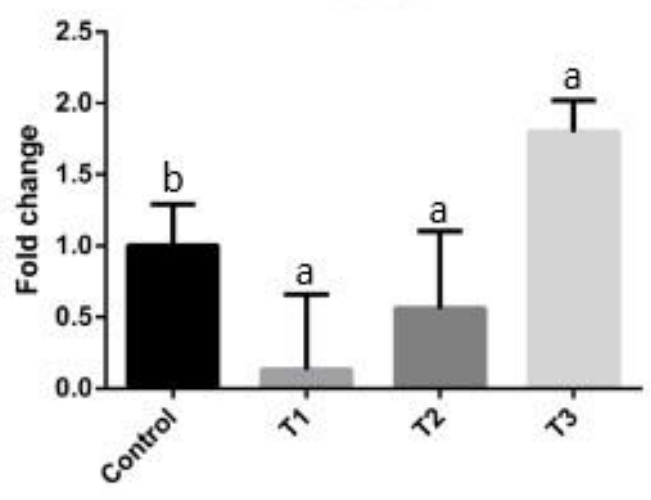

STAR

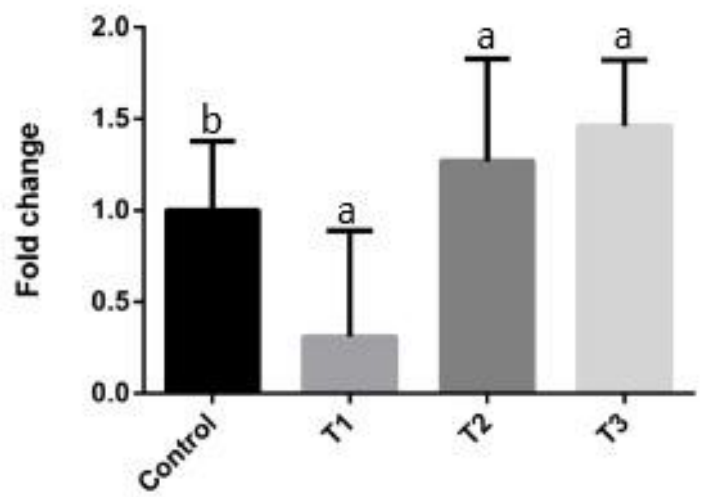

Figure 1. The relative expression levels of ovarian genes (ESR2 = estrogen receptor 2 (ER beta), FSHR $=$ follicle-stimulating hormone receptor, $P R L R=$ prolactin receptor, and $S T A R=$ steroidogenic acute regulatory protein) in quail, with different treatments. Letters $\mathrm{a}$, and $\mathrm{b}$ on the data bars indicate when $p$ $>0.05$ significant. CNT (control), T1 (basal diet supplemented with $0.1 \%$ Moringa oleifera seed powder), T2 (basal diet supplemented with $0.2 \%$ Moringa oleifera seeds powder), and T3 (basal diet supplemented with and $0.3 \%$ Moringa oleifera seeds powder).

\section{Discussion}

Excessive environmental heat is considered to be one of the major problems for laying birds. M. oleifera has potential as a valuable feed additive in animal nutrition, as it is rich in flavonoids and carotenoids, both of which are strong natural antioxidants [36]. It effectively prevents cellular oxidative damage by enhancing antioxidant enzyme activity, reducing free radicals, and decreasing lipid peroxidation [25]. The present study demonstrated the beneficial effects of the M. oleifera seed powder as a feed additive, in terms of alleviating the negative effects of heat stress on the laying, productive performance, and egg quality traits of Japanese quail. The feed intake of quail was significantly reduced in the T2 and T3 groups between 11 and 15 weeks of age, during the experiment. Furthermore, FCR was significantly higher in all supplemented groups (i.e., the T1, T2, and T3 groups) than in the CNT group, during the whole experiment. Hassan et al. [37] reported a higher FCR in broiler chickens reared under heat stress and fed a basal diet supplemented with $0.2 \%$ and $0.3 \% M$. oleifera leaves for 35 days. Furthermore, Ahmad et al. [38] reported improvements in FCR/dozen eggs and egg weight in laying hens administered a diet supplemented with $5 \mathrm{~g} / \mathrm{kg} M$. oleifera pod 
meal. Additionally, David et al. [39] observed that replacing antibiotic growth promoters in broiler diet with herbal supplements of $0.1 \%$ and $0.05 \%$ Moringa leaf powder had beneficial effects on the growth performance.

The adverse effect of heat stress on egg production is well recognized, but its mechanism of action remains unclear. Changes in avian reproductive performance mainly depend on the hypothalamic-pituitary-ovarian axis. Previous studies have reported that stress affects the secretion of LH and FSH in turkey poults [40], laying hens [8,41], and turkey hens [42]. Thus, successful and profitable poultry production requires understanding the negative effects of environmental conditions and overcoming them $[43,44]$. M. oleifera could be used as a valuable feed additive in animal nutrition due to its unique nutritional profile [21]. The Moringa seeds contain a high percentage of sweet oil (30\%- $40 \%$ of the seed weight) and contain around $76 \%$ of polyunsaturated fatty acids that can control cholesterol [45]. Additionally, the seeds of Moringa oleifera are a source of protein, iron, calcium, ascorbic acid vitamin $\mathrm{A}$, and antioxidant compounds, such as carotenoids, flavonoids, vitamin $\mathrm{E}$, and phenolics [46]. The presence of vitamins and minerals benefit the immune system and cure a myriad of diseases $[19,43,44,47,48]$.

Moreover, M. oleifera has been considered a dietary treatment option for heat stress in different animal species $[37,38,40,42,49]$. In the present study, M. oleifera seed powder supplementation influenced the expressions of ESR2, FSHR, STAR, and PRLR genes (Figure 1). Compared with the basal diet alone, basal diet supplemented with a $0.3 \%$ M. oleifera seed powder significantly increased the mRNA expressions of FSHR, ESR2, and STAR in the ovaries of laying quail. This effect was associated with the action of $0.3 \%$ M. oleifera seed powder in promoting the secretion of reproductive hormones, which could subsequently enhance the mRNA expressions of genes related to the reproductive axis. The activity of FSH and its receptors affect the development of reproductive organs as well as ovulation in follicles [50]. In the present study, dietary supplementation with $0.3 \%$ M. oleifera seed powder was considered ideal for improving the laying performance (egg weight and egg production) of quail subjected to heat stress (Table 5). Similarly, Riry et al. [51] and Ahmad et al. [38] reported the positive effects of $M$. oleifera seed meal on egg weight and egg production in laying quail and hens, respectively. Other studies have demonstrated the important role of ESR2 in the maintenance of ovarian function and effective reproduction, and a close relationship between ESR2 and laying performance was suggested [14,52]. Furthermore, Rangel et al. [53] suggested that STAR plays a vital role in the circadian control of steroidogenesis in the F1 follicle and subsequently in the circadian timing of ovulation. Based on these findings of previous studies and that of the present study regarding significant increases in egg production in the $\mathrm{T} 3$ group, we suggest that $0.3 \%$ M. oleifera seed powder supplementation in quail diet increases the expressions of some ovarian genes, thereby, improving the laying performance of quail. Conversely, the expressions of selected genes (ESR2 and FSHR) decreased in the T1 and T2 groups, possibly due to heat stress. Li et al. [11] have suggested that heat stress induces granulosa cell apoptosis and reduces steroidogenic gene mRNA expressions. Previous studies on mammals have demonstrated that heat stress inhibits the development of ovarian follicles and tends to cause ovarian regression $[54,55]$.

In the present study, the results concerning egg quality showed a consistent trend, and the best traits were observed in the T3 group. Riry et al. [51] observed that dietary supplementation with $M$. oleifera seed meal at $5 \%$ and $7.5 \%$, significantly improved the albumen (\%), yolk (\%), and the egg yolk index in laying quail. Furthermore, Abdel-Azeem et al. [56] recorded a high albumen weight, yolk weight, and shell thickness in laying chickens fed a diet supplemented with $0.5 \%, 1.5 \%$, and $2 \% M$. oleifera leaf powder. We could suggest that $M$. oleifera seed powder is beneficial as a dietary supplement in Japanese laying quail for improving productive performance, under heat stress.

\section{Conclusions}

Using M. oleifera seed powder as feed additives in Japanese laying quail diets could be a useful strategy for preventing the harmful effects of heat stress on performance and reproductive egg traits. 
The present study revealed that feed diets supplemented with $0.3 \%$ M. oleifera seed powder during the laying period, significantly enhanced egg productivity as well as egg quality traits, under heat stress rearing conditions. Furthermore, the expressions of some ovarian genes significantly improved in correlation to fortified feed diets with $0.2 \%$ or $0.3 \%$ M. oleifera seed powder.

Author Contributions: Conceptualization, H.A.B., and W.S.H.A.E.N.; methodology, R.A.-E., H.A.B., and W.S.H.A.E.N.; data curation, R.A.-E., M.A.E.N., and W.S.H.A.E.N.; writing-original draft preparation, H.A.B, W.S.H.A.E.N., J.S.A., S.N.M., A.A.A., and M.A.E.N.; writing-review and editing, J.S.A., S.N.M., A.A.A., and M.A.E.N. All authors have read and agreed to the published version of the manuscript.

Funding: This research was funded by King Saud University, Researchers Supporting Project (RSP-2019/149), King Saud University, Riyadh, Saudi Arabia.

Acknowledgments: The authors acknowledge King Saud University, Riyadh, Saudi Arabia, for funding this work through Researchers Supporting Project (RSP-2019/149).

Conflicts of Interest: The authors declare no conflict of interests.

\section{References}

1. Tunsaringkarn, T.; Tungjaroenchai, W.; Siriwong, W. Nutrient benefits of quail (Coturnix coturnix japonica) eggs. Int. J. Sci. Res. Publ. 2013, 3, 1-8.

2. Tolik, D.; Poawska, E.; Charuta, A.; Nowaczewski, S.; Cooper, R. Characteristics of egg parts, chemical composition and nutritive value of Japanese quail eggs-a review. Folia Biol. 2014, 62, 287-292. [CrossRef] [PubMed]

3. Atakisi, E.; Atakisi, O.; Yaman, H.; Arslan, I. Omega-3 fatty acid application reduces yolk and plasma cholesterol levels in Japanese quails. Food Chem. Toxicol. 2009, 47, 2590-2593. [CrossRef] [PubMed]

4. Abd El-Hack, M.E.; Alagawany, M.; Elrys, A.S.; Desoky, E.S.M.; Tolba, H.; Elnahal, A.S.; Swelum, A.A. Effect of forage Moringa oleifera L. (moringa) on animal health and nutrition and its beneficial applications in soil, plants and water purification. Agriculture 2018, 8, 145. [CrossRef]

5. Saeed, M.; Abbas, G.; Alagawany, M.; Kamboh, A.A.; Abd El-Hack, M.E.; Khafaga, A.F.; Chao, S. Heat stress management in poultry farms: A comprehensive overview. J. Therm. Biol. 2019, 84, 414-425. [CrossRef] [PubMed]

6. Abd El-Hack, M.E.; Abdelnour, S.A.; Taha, A.E.; Khafaga, A.F.; Arif, M.; Ayasan, T.; Swelum, A.A.; Abukhalil, H.H.; Alkahtani, S.; Aleya, L.; et al. Herbs as thermoregulatory agents in poultry: An overview. Sci. Total Environ. 2019, 134399. [CrossRef]

7. Deng, W.; Dong, X.; Tong, J.; Zhang, Q. The probiotic Bacillus licheniformis ameliorates heat stress-induced impairment of egg production, gut morphology, and intestinal mucosal immunity in laying hens. Poult. Sci. 2012, 91, 575-582. [CrossRef]

8. Rozenboim, I.; Tako, E.; Gal-Garber, O.; Proudman, J.; Uni, Z. The effect of heat stress on ovarian function of laying hens. Poult. Sci. 2007, 86, 1760-1765. [CrossRef]

9. Abdelnour, S.A.; Abd El-Hack, M.E.; Khafaga, A.F.; Arif, M.; Taha, A.E.; Noreldin, A.E. Stress biomarkers and proteomics alteration to thermal stress in ruminants: A review. J. Therm. Biol. 2019, 79, 120-134. [CrossRef]

10. Haugen, M.J.; Johnson, A.L. Bone morphogenetic protein 2 inhibits FSH responsiveness in hen granulosa cells. Reproduction 2010, 140, 551. [CrossRef]

11. Li, X.; Lu, Y.; Liu, X.; Xie, X.; Wang, K.; Yu, D. Identification of chicken FSHR gene promoter and the correlations between polymorphisms and egg production in Chinese native hens. Reprod. Domest. Anim. 2019, 54, 702-711. [CrossRef] [PubMed]

12. Shen, M.; Sun, H.; Qu, L.; Ma, M.; Dou, T.; Lu, J.; Guo, J.; Hu, Y.; Wang, X.; Li, Y. Genetic architecture and candidate genes identified for follicle number in chicken. Sci. Rep. 2017, 7, 1-10. [CrossRef] [PubMed]

13. Stephens, C.; Johnson, P. Bone morphogenetic protein 15 may promote follicle selection in the hen. Gen. Comp. Endocrinol. 2016, 235, 170-176. [CrossRef] [PubMed]

14. Wu, Y.; Xiao, H.; Liang, Z.; Pan, A.; Shen, J.; Pi, J.; Pu, Y.; Du, J.; Chen, Z. Differential expression profiling of estrogen receptor in the ovaries of two egg duck (Anas platyrhynchos) breeds. Czech J. Anim. Sci 2014, 59, 238-243. [CrossRef] 
15. Asli, M.M.; Hosseini, S.A.; Lotfollahian, H.; Shariatmadari, F. Effect of probiotics, yeast, vitamin E and vitamin $\mathrm{C}$ supplements on performance and immune response of laying hen during high environmental temperature. Int. J. Poult. Sci. 2007, 6, 895-900. [CrossRef]

16. Balnave, D.; Brake, J. Nutrition and management of heat-stressed pullets and laying hens. World's Poult. Sci. J. 2005, 61, 399-406. [CrossRef]

17. Al-Sagheer, A.A.; Abd El-Hack, M.E.; Alagawany, M.; Naiel, M.A.; Mahgoub, S.A.; Badr, M.M.; Hussein, E.O.; Alowaimer, A.N.; Swelum, A.A. Paulownia leaves as a new feed resource: Chemical composition and effects on growth, carcasses, digestibility, blood biochemistry, and intestinal bacterial populations of growing rabbits. Animals 2019, 9, 95. [CrossRef]

18. Dehshahri, S.; Wink, M.; Afsharypuor, S.; Asghari, G.; Mohagheghzadeh, A. Antioxidant activity of methanolic leaf extract of Moringa peregrina (Forssk.) Fiori. Res. Pharm. Sci. 2012, 7, 111.

19. Naiel, M.A.; Ismael, N.E.; Abd El-hameed, S.A.; Amer, M.S. The antioxidative and immunity roles of chitosan nanoparticle and vitamin C-supplemented diets against imidacloprid toxicity on Oreochromis niloticus. Aquaculture 2020, 523, 735219. [CrossRef]

20. Mbikay, M. Therapeutic potential of Moringa oleifera leaves in chronic hyperglycemia and dyslipidemia: A review. Front. Pharm. 2012, 3, 24. [CrossRef]

21. Arif, M.; Hayat, Z.; Abd El-Hack, M.E.; Saeed, M.; Imran, H.M.; Alowaimer, A.N.; Saadeldin, I.M.; Taha, A.E.; Swelum, A.A. Impacts of supplementing broiler diets with a powder mixture of black cumin, Moringa and chicory seeds. S. Afr. J. Anim. Sci. 2019, 49, 564-572. [CrossRef]

22. Moyo, B.; Oyedemi, S.; Masika, P.; Muchenje, V. Polyphenolic content and antioxidant properties of Moringa oleifera leaf extracts and enzymatic activity of liver from goats supplemented with Moringa oleifera leaves/sunflower seed cake. Meat Sci. 2012, 91, 441-447. [CrossRef] [PubMed]

23. Saini, R.; Shetty, N.; Prakash, M.; Giridhar, P. Effect of dehydration methods on retention of carotenoids, tocopherols, ascorbic acid and antioxidant activity in Moringa oleifera leaves and preparation of a RTE product. J. Food Sci. Technol. 2014, 51, 2176-2182. [CrossRef] [PubMed]

24. Ahmed, N.F.; Sadek, K.M.; Soliman, M.K.; Khalil, R.H.; Khafaga, A.F.; Ajarem, J.S.; Maodaa, S.N.; Allam, A.A. Moringa Oleifera Leaf Extract Repairs the Oxidative Misbalance following Sub-Chronic Exposure to Sodium Fluoride in Nile Tilapia Oreochromis niloticus. Animals 2020, 10, 626. [CrossRef] [PubMed]

25. Sreelatha, S.; Padma, P. Antioxidant activity and total phenolic content of Moringa oleifera leaves in two stages of maturity. Plant Foods Human Nutr. 2009, 64, 303. [CrossRef]

26. Ashour, E.A.; El-Kholy, M.S.; Alagawany, M.; Abd El-Hack, M.E.; Mohamed, L.A.; Taha, A.E.; Sheikh, A.I.E.; Laudadio, V.; Tufarelli, V. Effect of Dietary Supplementation with Moringa oleifera Leaves and/or Seeds Powder on Production, Egg Characteristics, Hatchability and Blood Chemistry of Laying Japanese Quails. Sustainability 2020, 12, 2463. [CrossRef]

27. Thu Lan, L.T.; Trong Ngu, N.; Thai Hung, L.; Nguyen Han, L.V.; Hong Nhan, N.T. Moringa oleifera and Calliandra calothyrsus leaf powder as feed supplement in the diet of laying Japanese quails. Livest. Res. 2019, 31.

28. A.O.A.C. Official Methods of Analysis; Patricia, C. Association of Official Analytical Chemists (AOAC), 16th ed.; A.O.A.C. Official Methods of Analysis: Arlington, VA, USA, 1995.

29. Reddy, P.; Reddy, V.; Reddy, C.; Rao, P. Egg weight, shape index and hatachability in Khaki Campbell duck eggs. Indian J. Poult. Sci. 1979, 14, 26-32.

30. Romanoff, A.L.; Romanoff, A.J. The Avian Egg; John Wiley and Sons: New York, NY, USA, 1949.

31. Cotta, T. Chicken Reproduction and Egg Production; UFLA-Faepe: Lavras, Brazil, 1997; pp. 81-92.

32. Abd El Naby, W.S.H.; Basha, H.A. Influence of Lighting Systems on Some Muscle Development Related Genes and Production Traits in Japanese quail. AJAVA 2018, 13, 295-300. [CrossRef]

33. Rao, D.D.; Senzer, N.; Wang, Z.; Kumar, P.; Jay, C.M.; Nemunaitis, J. Bifunctional short hairpin RNA (bi-shRNA): Design and pathway to clinical application. In siRNA Des.; Springer: Clifton, NJ, USA, 2013; pp. 259-278.

34. Kim, H.-Y. Statistical notes for clinical researchers: Assessing normal distribution (2) using skewness and kurtosis. Rest. Dent. Endod. 2013, 38, 52-54.

35. Duncans, D. Multiple range and multiple F. test. Biometrics 1955, 11, 1-42. [CrossRef] 
36. EL-Shoukary, R.D.; Darwish, M.H.; Abdel-Rahman, M.A. Behavioral, performance, carcass traits and hormonal changes of heat stressed broilers feeding black and coriander seeds. J. of Adv. Vet. Res. 2014, 4, 97-101.

37. Hassan, H.; El-Moniary, M.; Hamouda, Y.; El-Daly, E.F.; Youssef, A.W.; El-Azeem, N.A. Effect of different levels of Moringa oleifera leaves meal on productive performance, carcass characteristics and some blood parameters of broiler chicks reared under heat stress conditions. Asian J. Anim. Vet. Adv. 2016, 11, 60-66. [CrossRef]

38. Ahmad, S.; Khalique, A.; Pasha, T.; Mehmood, S.; Hussain, K.; Shaheen, M.; Naeem, M.; Shafiq, M. Effect of Moringa oleifera (Lam.) pods as feed additive on egg antioxidants, chemical composition and performance of commercial layers. South African J. of Anim. Sci. 2017, 47, 864-874. [CrossRef]

39. David, L.; Vidanarachchi, J.; Samarasinghe, K.; Cyril, H.; Dematawewa, C. Effects of moringa based feed additives on the growth performance and carcass quality of broiler chicken. Trop. Agric. Res. 2012, 24, 12-20. [CrossRef]

40. Opel, H.; Proudman, J.A. Effects of repeated handling and blood sampling on plasma prolactin levels in young turkeys. Poult. Sci. 1982, 61, 1390-1398.

41. Johnson, A.L. Comparison of three serial blood sampling techniques on plasma hormone concentrations in the laying hen. Poult. Sci. 1981, 60, 2322-2327. [CrossRef]

42. El Halawani, M.; Silsby, J.; Fehrer, S.; Behnke, E. The influence of acute or repeated immobilization on plasma prolactin levels in the turkey (Meleagris gallopavo). Gen. Comp. Endocrinol. 1985, 59, 410-415. [CrossRef]

43. Arif, M.; Iram, A.; Bhutta, M.A.; Naiel, M.A.; Abd El-Hack, M.E.; Othman, S.I.; Allam, A.A.; Amer, M.S.; Taha, A.E. The Biodegradation Role of Saccharomyces cerevisiae against Harmful Effects of Mycotoxin Contaminated Diets on Broiler Performance, Immunity Status, and Carcass characteristics. Animals 2020, 10, 238. [CrossRef]

44. El-Shall, N.A.; Awad, A.M.; Abd El-Hack, M.E.; Naiel, M.A.; Othman, S.I.; Allam, A.A.; Sedeik, M.E. The Simultaneous Administration of a Probiotic or Prebiotic with Live Salmonella Vaccine Improves Growth Performance and Reduces Fecal Shedding of the Bacterium in Salmonella-Challenged Broilers. Animals 2020, 10, 70. [CrossRef]

45. Berger, M.; Habs, M.; Jahn, S.; Schmahl, D. Toxicological assessment of seeds from Moringa oleifera and Moringa stenopetala, two highly efficient primary coagulants for domestic water treatment of tropical raw waters. East African Med. J. 1984, 61, 712.

46. Sultana, B.; Anwar, F. Flavonols (kaempeferol, quercetin, myricetin) contents of selected fruits, vegetables and medicinal plants. Food Chem. 2008, 108, 879-884. [CrossRef] [PubMed]

47. Gombart, A.F.; Pierre, A.; Maggini, S. A Review of Micronutrients and the Immune System-Working in Harmony to Reduce the Risk of Infection. Nutrients 2020, 12, 236. [CrossRef] [PubMed]

48. Naiel, M.A.; Ismael, N.E.; Shehata, S.A. Ameliorative effect of diets supplemented with rosemary (Rosmarinus officinalis) on aflatoxin B1 toxicity in terms of the performance, liver histopathology, immunity and antioxidant activity of Nile Tilapia (Oreochromis niloticus). Aquaculture 2019, 511, 734264. [CrossRef]

49. Gopalakrishnan, L.; Doriya, K.; Kumar, D.S. Moringa oleifera: A review on nutritive importance and its medicinal application. Food Sci. Human Wellness 2016, 5, 49-56. [CrossRef]

50. George, J.W.; Dille, E.A.; Heckert, L.L. Current concepts of follicle-stimulating hormone receptor gene regulation. Biol. Reprod. 2011, 84, 7-17. [CrossRef]

51. Riry, F.; Elkloub, K.; Moustafa, M.; MAM, M.; Hanan, A.; Youssef, S. Effect of partial replacement of soybean meal by moringa oleifera seed meal on japanese quail performance during laying period. Egy. Poult. Sci. J. 2018, 38, 255-267.

52. Knapczyk, K.; Duda, M.; Durlej, M.; Galas, J.; Koziorowski, M.; Slomczynska, M. Expression of estrogen receptor $\alpha(E R \alpha)$ and estrogen receptor $\beta(E R \beta)$ in the ovarian follicles and corpora lutea of pregnant swine. Domest. Anim. Endocrinol. 2008, 35, 170-179. [CrossRef]

53. Rangel, P.; Rodríguez, A.; Rojas, S.; Sharp, P.; Gutierrez, C. Testosterone stimulates progesterone production and STAR, P450 cholesterol side-chain cleavage and LH receptor mRNAs expression in hen (Gallus domesticus) granulosa cells. Reprod. 2009, 138, 961-969. [CrossRef]

54. Aroyo, A.; Yavin, S.; Arav, A.; Roth, Z. Maternal hyperthermia disrupts developmental competence of follicle-enclosed oocytes: In vivo and ex vivo studies in mice. Theriogenology 2007, 67, 1013-1021. [CrossRef] [PubMed] 
55. Wolfenson, D.; Lew, B.; Thatcher, W.; Graber, Y.; Meidan, R. Seasonal and acute heat stress effects on steroid production by dominant follicles in cows. Anim. Reprod. Sci. 1997, 47, 9-19. [CrossRef]

56. Abdel-Azeem, A.; Mohamed, F.; El-Shiekh, S.; Hessin, A. Maximizing Productivity of Lohmann Chickens by Feeding Diets Inclusion Different Levels of Moringa oleifera Leaf Powder as a Safe Feed Additive. J. Anim. Poult. Prod. 2017, 8, 319-328. [CrossRef]

C 2020 by the authors. Licensee MDPI, Basel, Switzerland. This article is an open access article distributed under the terms and conditions of the Creative Commons Attribution (CC BY) license (http://creativecommons.org/licenses/by/4.0/). 